\title{
A NEW PROCESS IMPROVEMENT APPROACH FOR MANAGEMENT CONSULTANCY ORGANISATIONS
}

\author{
M. de Vries and P.J. Conradie \\ Department of Industrial and Systems Engineering \\ University of Pretoria, South Africa \\ marne.devries@up.ac.za, pieter.conradie@up.ac.za
}

\begin{abstract}
Management consultancy organisations of the $21^{\text {st }}$ century realise that they need to move away from balance sheet accounting systems as the primary tool of management. Intangible assets, such as knowledge, skills and process assets, may be worth more than their physical assets, and require effective management to gain a competitive advantage. Many models for process-improvement and knowledge management that currently exist could be used in leveraging organisational intangible assets. Though the intricate interaction between the domains of process improvement management and knowledge management is clear in current models, a fully integrated model does not exist. The aim of this article is to demonstrate the integration possibilities of process improvement and knowledge management in an attempt to improve the practices of both during the same exercise, using an integrated model.
\end{abstract}

\section{OPSOMMING}

Bestuurskonsultasie-organisasies van die $21^{\text {ste }}$ eeu besef dat hul moet wegbeweeg van balansstaat gebaseerde rekenkundige stelsels as die primêre gereedskapstuk vir bestuur. Ontasbare bates, soos kennis, vaardighede en prosesbates, mag meer waardevol wees as fisiese bates, en moet effektief bestuur word om ' $n$ mededingende voordeel te behou. Talle modelle vir prosesverbeteringsbestuur en kennisbestuur bestaan tans en word ingespan om optimale benutting van die ontasbare bates te verseker. Alhoewel die ingewikkelde interaksie tussen die velde van prosesverbeteringsbestuur en kennisbestuur duidelik is in die bestaande modelle, bestaan daar nie ' $n$ geïntegreerde model nie. Hierdie artikel demonstreer die integrasie moontlikhede van prosesverbeteringsbestuur en kennisbestuur deur gebruik te maak van ' $n$ geïntegreerde model, sodat praktyke van beide velde gedurende dieselfde oefening verbeter word. 


\section{INTRODUCTION}

The new e-business economy of today has changed the understanding of what creates value for organisations. Intangible assets (e.g. intellectual capital, which includes the knowledge and skills of employees) are now among the most important sources of value creation. A company may have a book value (appearing on its balance sheet) of R10,000,000, yet be worth R100,000,000 on the stock exchange. Intellectual capital accounts for the R90,000,000 difference (Bahra [7]).

The World Bank (cited in Bahra [7], p. 49) noted that "the balance between knowledge and resources has shifted so far towards the former that knowledge may have become the most important factor determining the standard of living...Today's most technologically advanced economies are truly knowledge based". "To make knowledge work productive is the great management task of this century, just as making manual work productive was the great management task of the last century" (Drucker, cited in Bahra [7], p. 58).

People's skills, knowledge and creativity (also called human capital) have become important in the creation of economic value (Bahra [7]). Employees also realise their value, and command the highest fees from organisations that will "recognise and respect their talent and allow them to learn and earn and develop their skill base" (Bahra [7], p. 51). The relationship between employee and employer is changing the balance of power is shifting to the talented, creative individual. Employees realise that job security is something of the past. "Three career moves and eight job changes will be the norm in the future” (Walter, cited in Bahra [7], p. 49).

Consultancy firms are some of the very first adopters of KM (Knowledge Management) practices. This sector's main asset is people. Consequently, consultancy firms invest heavily in training and development, but are also characterised by a high staff turnover rate. These organisations are engaged in multiple projects with various clients. Each project contains a set of project-specific processes, tasks and project team members. The challenge is to utilise employee expertise and knowledge efficiently within consultancy firms, ensuring that KM investments are balanced with strategic business objectives, other organisational improvement initiatives, and their relative value addition. Due to the strong process orientation of management consultancy firms, KM and organisational learning initiatives need to enhance this process perspective.

This article explores the capabilities of current models (especially maturity models) to integrate the process-orientation perspective with knowledge management. A new model is defined in terms of the existing models, identifying possible overlaps and deficiencies, while applying the existing models to the project management context of management consultancy organisations. The model has been partially validated at a management consultancy organisation. This article only highlights the results and conclusions of the validation exercise. 


\section{A FOUNDATION FOR INTEGRATION}

Literature reveals the integrative nature of various disciplines, which indicates the necessity to view business strategy, business performance measurement, process management, and KM from an holistic perspective. The purpose of this section is to discuss those disciplines and relevant measurement models that provide a foundation for integration.

\subsection{Knowledge Management}

$\mathrm{KM}$ is a philosophy that has the primary objective of optimising knowledge in an organisation. Abell and Oxbrow [8] believe that nobody can manage knowledge. "What you can do, what a company does, is to manage the environment that optimises knowledge" (Abell and Oxbrow [8], p. 36). The managed environment should lead to an optimum corporate capability - "a unique mix of skills, expertise, processes, management and intellectual capital that enables an organisation to respond to and develop its markets" (Abell and Oxbrow [8], p. 105).

The champions and disciples of KM believe that KM should achieve the following key objectives in an organisation:

- "Know what you know,

- learn what you need to know, and

- $\quad$ use knowledge effectively" (Abell and Oxbrow [8], p. 39)

\section{Knowledge Management processes}

Davenport, Jarvenpaa and Beers (cited in Ahmed et al [6]) identify five primary process orientations to knowledge:

1. Finding existing knowledge or searching for knowledge among multiple sources.

2. Creating new knowledge.

3. Packaging or assembling knowledge without creating new knowledge, e.g. publishing.

4. Applying or using existing knowledge.

5. Reusing knowledge or leveraging knowledge previously obtained by the organisation.

KM processes enable the creation of effective and robust corporate memories, facilitating organisational learning from previous corporate experience (Abell and Oxbrow [8]). The challenge is to create processes that will truly create a dynamic and living corporate memory, rather than a collection of static electronic filing cabinets. 


\subsection{Knowledge Management in consultancy firms}

\section{Knowledge elements in management consultancy firms}

Apostolou and Mentzas [12] state that the need to manage knowledge increases proportionally with the service intensity of companies. Service-oriented, knowledgeintensive companies also share common characteristics: their "products" are intangible (not consisting of goods); their "production process" is non-standardised and relies on team-work; most of their employees are educated and creative; their customers are treated individually; and "products" are tailored to their clients' requirements.

Management consulting firms (a sub-set of service-oriented companies) share all the above-mentioned characteristics. It is not surprising that consultancy firms consider $\mathrm{KM}$ to be a core and strategic approach for gaining a competitive advantage (Dunford [10]). Global management consulting industries are often considered to be the prime example of knowledge-intensive firms (Alvesson and Starbuck, cited in Werr [11]).

The current understanding of $\mathrm{KM}$ in management consulting organisations is characterised by a classification of organisational knowledge as either articulate knowledge (represented by documents and databases) or tacit knowledge (represented by experience and skills possessed by individuals. Werr [11] performed an empirical study based on case studies in standardised service consultancy organisations - Accenture and Cap Gemini Ernst \& Young. The aim was to investigate the potential complementarities between explicit knowledge (viewing knowledge as theory) and tacit knowledge (viewing knowledge as practice) in the context of management consulting organisations. Werr [11] argues that the simultaneous existence and complementary use of the two knowledge types represents the essence of organisational competence in management consulting.

\section{Project management in management consultancy firms}

Management consultancy firms are responsible for supplying solutions to problems experienced by their clients. The solutions are unique to each client and are delivered within a specific time frame. Management consultancy firms usually employ project management processes to manage several contracts with clients.

The Harvard Business School [13] identified four generic project management phases:

- Defining and organising the project.

- Planning the project.

- Managing the project execution.

- Closing down the project.

The nature of these processes, as well as the project team approach, usually leads to decentralisation and knowledge fragmentation. After completing the project, team 
members are re-allocated to other projects and project documentation is stored in project folders, without proper referencing for future use (Disterer [14]).

Each project management phase could be effectively supported by several KM initiatives to increase the overall organisational efficiency. Figure 1 (based on the four generic phases of The Harvard Business School [13]) highlights the vast number of opportunities for containing and sharing project-related knowledge. The rectangles represent project-related processes, the rounded blocks signify KM processes, and arrow-blocks indicate human resource management processes.

\subsection{Performance measurement using benchmarking}

"What gets measured, gets done” (Deming in Eckes [2], p. 70).

Business strategies not only direct businesses towards business decisions and strategic projects, but also determine the various measures that will be used to assess strategy implementation performance. Measurements are used to identify problem areas, and direct attention to low-scoring measures that may have a high impact on the overall business performance.

Various theories exist on measuring business performance. Today, most companies adopt a balanced view on measuring performance - not only managing financial performance, but including various other perspectives, such as customer satisfaction, internal business process improvement, and individual learning and growth. Research conducted on a number of leading European companies indicated a trend in managing performance improvement through focusing on the underlining drivers of performance (e.g. processes or resources) and sustaining the capabilities and competencies that allow companies to compete effectively in future (Bourne, Franco and Wilkes [16]).

Companies may either measure business performance against pre-defined targets (derived from strategic business goals) or against performance levels of similar companies (that is, benchmarking). Buytendijk et al [30] believe that benchmarking is one of the more effective methodologies when employed correctly. The aim is to follow the behaviour of a specific firm, industry or sector that excels in performance (Tiwana [9]), thus linking performance with reality. It is a practical approach based on best practices, and takes market reality as its starting point (Buytendijk et al [30]).

This approach ties in with the general representation of maturity models benchmarking a company against fixed maturity levels. Various maturity models will be discussed next.

\subsection{Maturity models and audit models}

Maturity models stem from Watts Humphrey's philosophy that organisations had to eliminate implementation problems in a specific order if they were to create an 


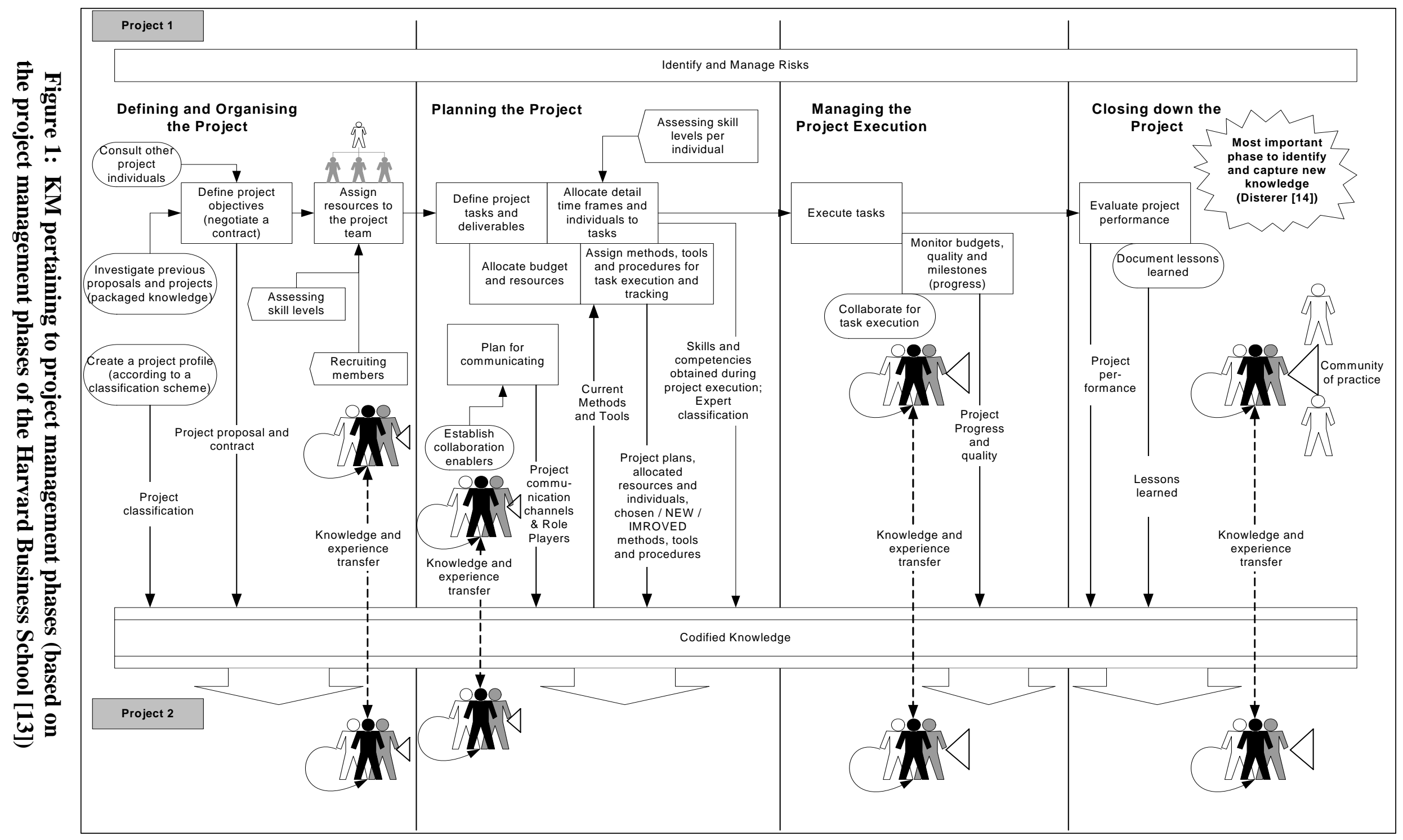


environment conducive to continuous improvement (Curtis et al [4]). Organisations perform best if "they focus their process improvement efforts on a manageable number of process areas that requires increasingly sophisticated effort as the organisation improves” (CMMI Product Team [3]).

Maturity models provide an evolutionary path, increasing process maturity in stages. These stages are ordered, so that each stage provides a foundation for improvements in the next stage (CMU/SEI [15]). A roadmap is thus provided for continuous process improvement, and is not intended to provide a quick solution for projects in trouble (CMU/SEI [15]). Maturity models, in general, apply the process management concepts of Total Quality Management. Maturity models could be used to address one or more of the following objectives:

1. Performing an audit regarding a specific domain of practice to assess the current organisational level of maturity in relation to a set of pre-defined criteria.

2. Defining maturity levels and a set of pre-defined criteria per maturity level (as specified by the author of the specific maturity model) to benchmark a company against similar companies (see Figure 2).

3. Defining capability maturity levels and subsequent improvement objectives and practices (per level) parallel to strategic business objectives. The defined capability maturity levels are used as a business performance measurement tool, measuring certain process areas (see Figure 3).

Many audit models follow the same approach and objectives detected in maturity models. These models also provide a framework for assessing the current organisational maturity regarding a specific domain of practice. The outcome of an audit may then be used to direct improvement initiatives, such as new or adapted practices, processes and technologies.

Literature revealed the following maturity models and audit models relevant to the following domains:

- $\quad$ Systems Engineering (addressed by the CMMI - Capability Maturity Model Integration, developed by the Software Engineering Institute of Carnegie-Mellon University (CMMI Product Team [3])).

- Software Engineering (addressed by the CMMI, (CMMI Product Team [3])).

- Integrated Product and Process Development (addressed by the CMMI, (CMMI Product Team [3])).

- $\quad$ Supplier Sourcing (addressed by the CMMI, (CMMI Product Team [3])).

- Knowledge Management (addressed by the Knowledge Formula of Hazlett and Gallaghers, the Knowledge Management Maturity Model of Siemens, Knowledge Management Framework Assessment Exercise of KPMG, the KM Model of Infosys Technologies, IT Advisor for Knowledge Management by Microsoft, and others (Weerdmeester, Pocaterra, \& Hefke [1])). 
- Workforce Management (P-CMM - People Capability Maturity Model of Curtis, Hefley \& Miller (Curtis et al [4])).

Maturity models could have different representations: staged or continuous. The staged model contains maturity levels and is used to deduce a single maturity rating for the complete organisation, which allows comparisons among organisations. The continuous model contains capability levels that could be applied to single process areas. This mode is used to define improvement objectives for specific process areas in accordance with, and parallel to, strategic business objectives.

Figure 2 illustrates the different maturity levels that are used in the staged representation of CMMI.

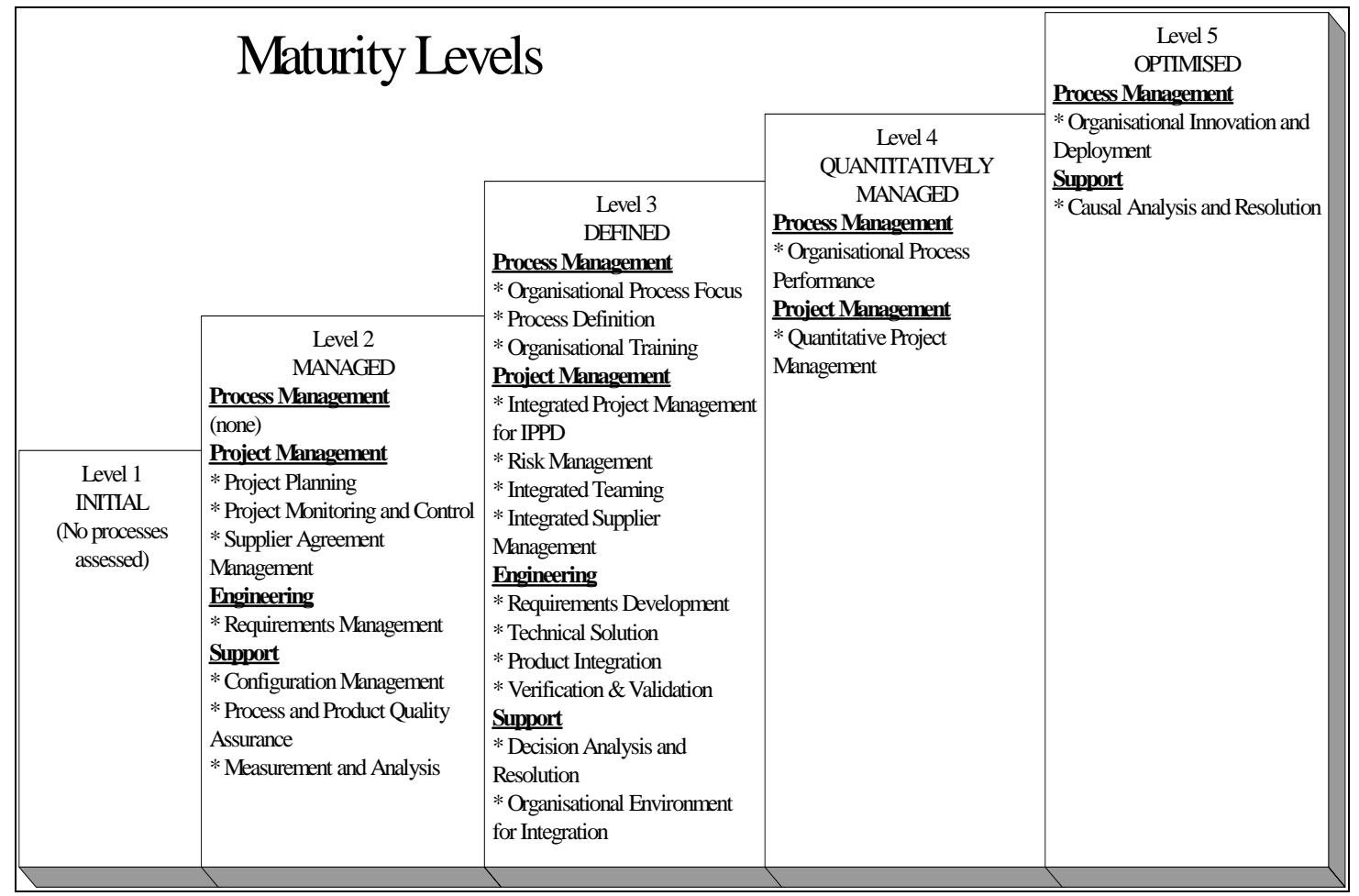

Figure 2: Process areas per maturity level (CMMI Product Team [3])

Maturity models have the following common components (illustrated in Figure 4):

- Maturity levels, defining an organisation's overall maturity in terms of a number of progressive levels (e.g. levels 1 to 5). Each maturity level contains a predefined set of process areas. 


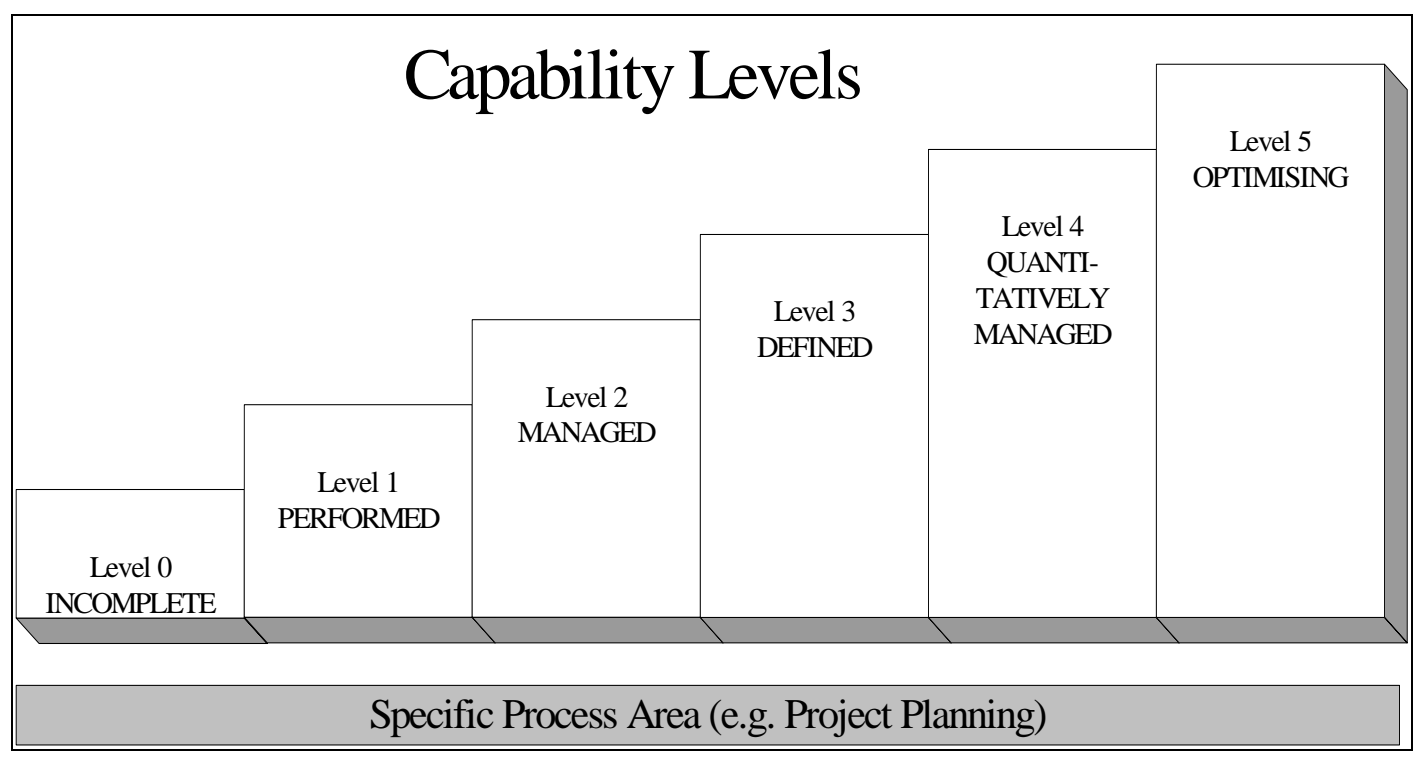

Figure 3: Capability levels for a single process area (CMMI Product Team [3])

- Process areas. Each process area contains generic and specific goals, as well as generic and specific practices.

- Generic / specific goals and practices.

- Categorisation of practices - implementation / institutionalisation practices. Specific practices are classified as implementation practices and are those practices that should typically be performed to achieve the specific goals of the process area. Generic practices are classified as institutionalisation practices and enable the organisation to institutionalise best practices so that they are effective, repeatable, and lasting (Curtis et al, [4]).

- Categorisation of required, expected or informative components. Process area goals (specific and generic) are classified as required, as they determine process area achievement. Specific and generic practices are classified as expected, as they guide individuals in implementing improvements to achieve process area goals. Supplementary information regarding goals, practices or elaborations are classified as informative (CMMI Product Team [3]).

Thorough analysis of existing maturity models revealed the following: although literature signifies a strong interaction between the various domains of process improvement / knowledge management, no single maturity model fully incorporates both domains. This deficiency is discussed further in the next section.

\subsection{Requirement for a blended model}

Maier and Remus [17] performed an empirical study to investigate the use of KM systems in the 500 largest German companies and the top 50 banking and insurance companies. They found that process orientation was not focused in most of the KM 
activities in these organisations, despite the fact that most organisations had already implemented process management programmes in the past.

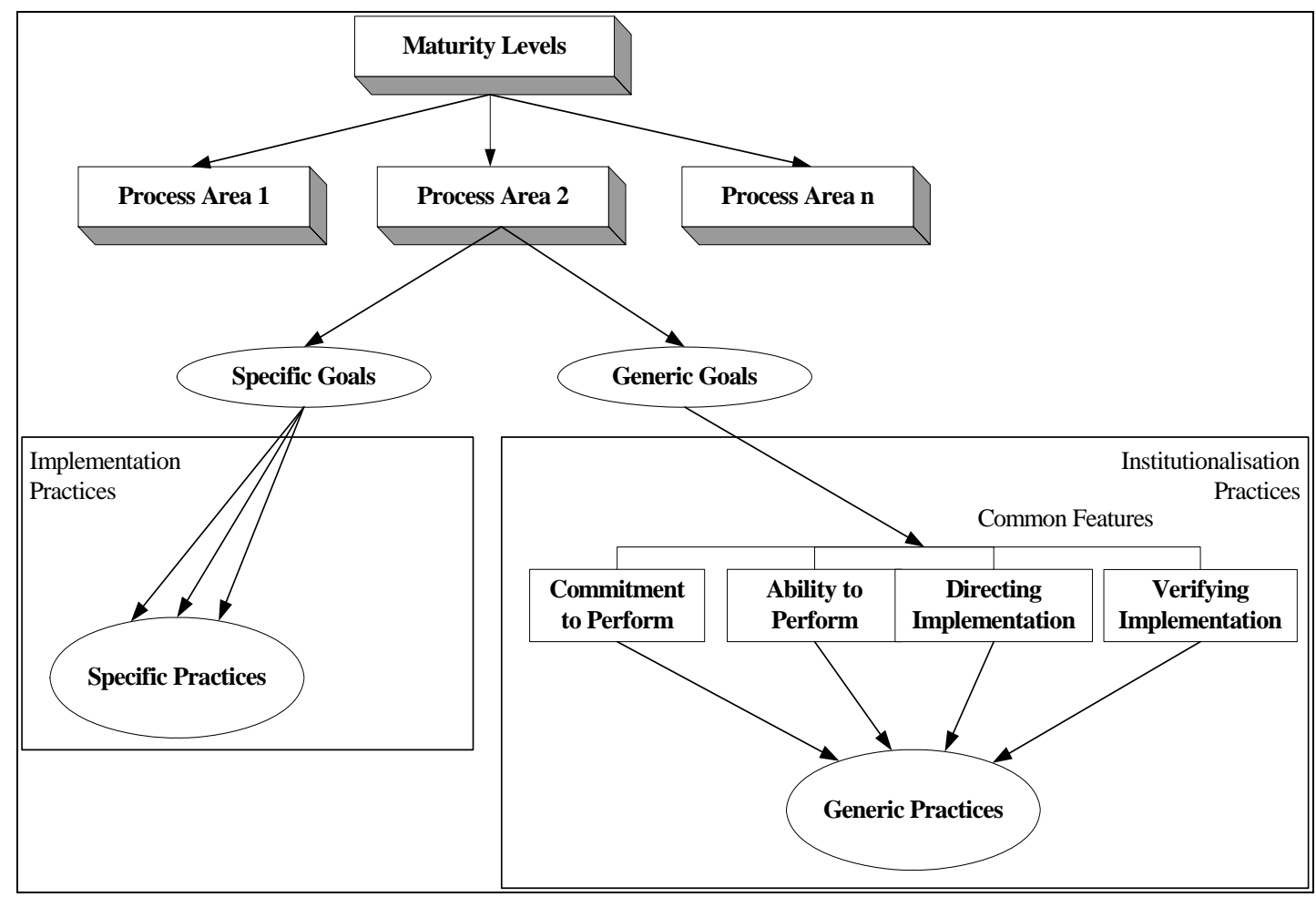

Figure 3: CMMI components for the staged representation (CMMI Product Team [3])

Ahmed [6] states that many companies fail to integrate the various types of processes, including operational, behavioural (communication and individual learning), and managerial processes. These companies usually focus their attention on individual operational processes, consequently delivering sub-optimal results.

It is proposed that various maturity models be synthesised into a single model to address the interrelationships and interactivity of closely-related domains (process improvement management, knowledge, and workforce-capability management) for management consultancy organisations. The aim is to improve the effectiveness of the current stand-alone domain models by utilising their synergistic capabilities.

\section{CONCEPTUAL MODEL}

Using the framework (defined in the previous section), the following approach was used in developing an integrated process improvement management / KM maturity model: 


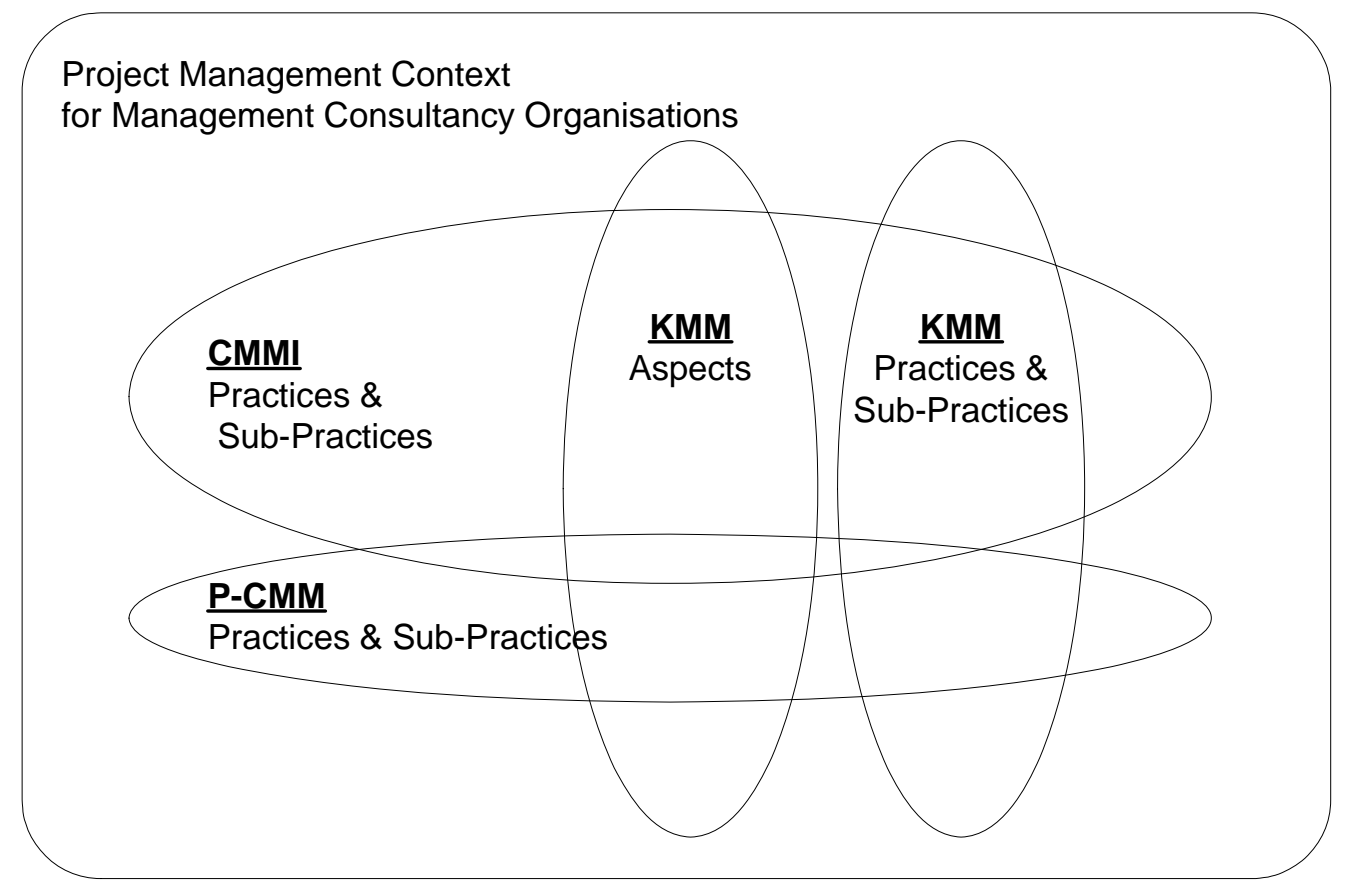

Figure 4: Context for analysing model overlaps and deficiencies

1. Re-defining the maturity levels of a blended model for management consultancy organisations, using existing maturity models.

2. Delineating the model construction process (6 steps) for designing detail elements of the blended model.

The approach is depicted in Figure 6..

The blended model was constructed by using model components of the following existing reconcilable models:

- CMMI: Capability Maturity Model Integration (CMMI Product Team [3]).

- P-CMM: People Capability Maturity Model (Curtis et al [4]).

- Knowledge Management Framework Assessment Model of KPMG (Parlby [18]).

- $\quad$ Siemens Knowledge Management Maturity Model (Weerdmeester et al [1]).

- KMM from Infosys Technologies (Kochikar [5]).

\subsection{Re-defining the maturity levels of a blended model}

The CMMI maturity level descriptions were used to define those of the blended model. These levels were reinterpreted in the context of the new, blended approach.

Table 1 maps other maturity model descriptions according to the CMMI description in terms of their intent and maturity level objectives. 


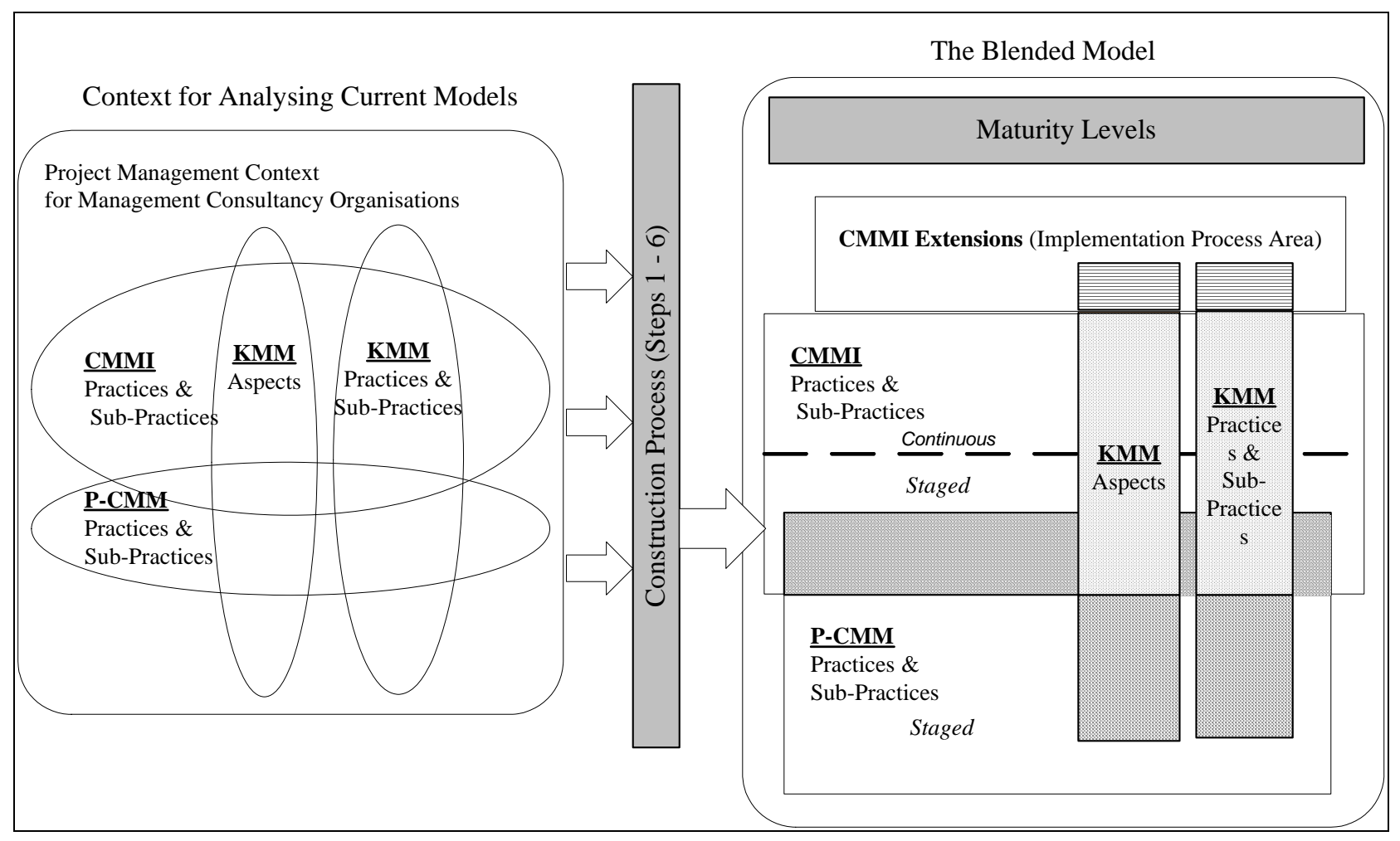

Figure 5: Constructing a blended model

\begin{tabular}{|c|c|c|c|c|}
\hline CMMI & P-CMM & KPMG Model & $\begin{array}{l}\text { Siemens } \\
\text { Model }\end{array}$ & $\begin{array}{l}\text { Infosys Technologies } \\
\text { Model }\end{array}$ \\
\hline Initial & Initial & Knowledge chaotic & Initial & Default \\
\hline Managed & Managed & Knowledge aware & Repeated & Reactive \\
\hline Defined & Defined & Knowledge focused & Defined & Aware \\
\hline $\begin{array}{l}\text { Quantitatively } \\
\text { Managed }\end{array}$ & Predictable & Knowledge managed & Managed & Convinced \\
\hline Optimising & Optimising & Knowledge Centric & Optimising & Sharing \\
\hline
\end{tabular}

Table 1: Maturity level map

The following maturity level definitions were adopted:

Initial: The organisation has no uniform way of performing work - processes are reinvented on each project. Managers struggle to estimate project progress and control costs, schedules (including task responsibilities) or product quality. No standardised processes or practices are followed, and project members do not reuse or improve previous project experiences or artefacts. These projects are only successful if exceptional individuals are on board. There is a strong dependence on individual skills, abilities and tacit knowledge, rather than sharing and building on previous organisational experience and knowledge.

Managed: The organisation creates an environment of repeatability - the ability to repeat tasks consistently. This environment is attained by establishing control over 
project commitments, baselines and workforce practices on a project and organisational unit level.

Defined: The organisation defines its best practices and integrates them into a common process. Best practices (also regarding KM) are documented, integrated into a standardised process, trained and implemented by the entire organisation. Workforce competencies (aggregated knowledge, skills, and process abilities) are linked to the defined processes, and knowledge usage is evident in the standardised processes. Standardised processes and practices also encourage/reward knowledge working/sharing (e.g. adapting compensating systems, technical infrastructure, and appointment of knowledge officers). A participatory and knowledge-sharing culture is nurtured, enabling an organisation to gain maximum benefit from its workforce competencies and process implementation experiences. This level is characterised by the implementation of various KM techniques (e.g. communities of practice, knowledge maps, and storytelling).

Quantitatively Managed: The current process performance, the capability for performing work, and the actual creation, usage and sharing of internal and external knowledge sources are quantifiable. This quantification may be used to predict future performance, identify deviations from expected results, and initiate corrective action. Established processes can now be trusted and may be preserved as organisational assets, which may be reused by others in the organisation. Management now starts to utilise the insightful process knowledge to direct its attention to strategic issues and improvement initiatives.

Optimising: The organisation uses its statistical process data (in combination with its strategic objectives) to identify processes that may benefit most from improvement actions. This may lead to linear, incremental process improvement initiatives, as well as breakthrough, quantum improvement initiatives. The culture created at this level is one of continuous improvement, learning and performance excellence.

\subsection{Delineating the model construction process}

A model construction process was required to identify processes, goals and practices from various maturity models, analysing and extending these to address all project management phases that are present in management consultancy organisations.

The following model construction process was defined:

1. Identify and analyse all process area categories, process areas, goals and practices of various process / people / knowledge management maturity models.

2. Graphically demonstrate the interaction of CMMI and P-CMM process areas, overlapping processes, as well as embedded KM practices.

3. Discuss the process areas, goals and practices and how they demonstrate KM practices for management consultation organisations.

4. Define process-overlaps between CMMI and P-CMM and KM models. 
5. Demonstrate how CMMI process areas address various project management phases, and define additional process areas, practices, and informative components to address current model deficiencies.

6. Construct a reduced model (the blended model) that will be validated in practice.

The construction process produced the conceptual model that is depicted in

Figure 6.

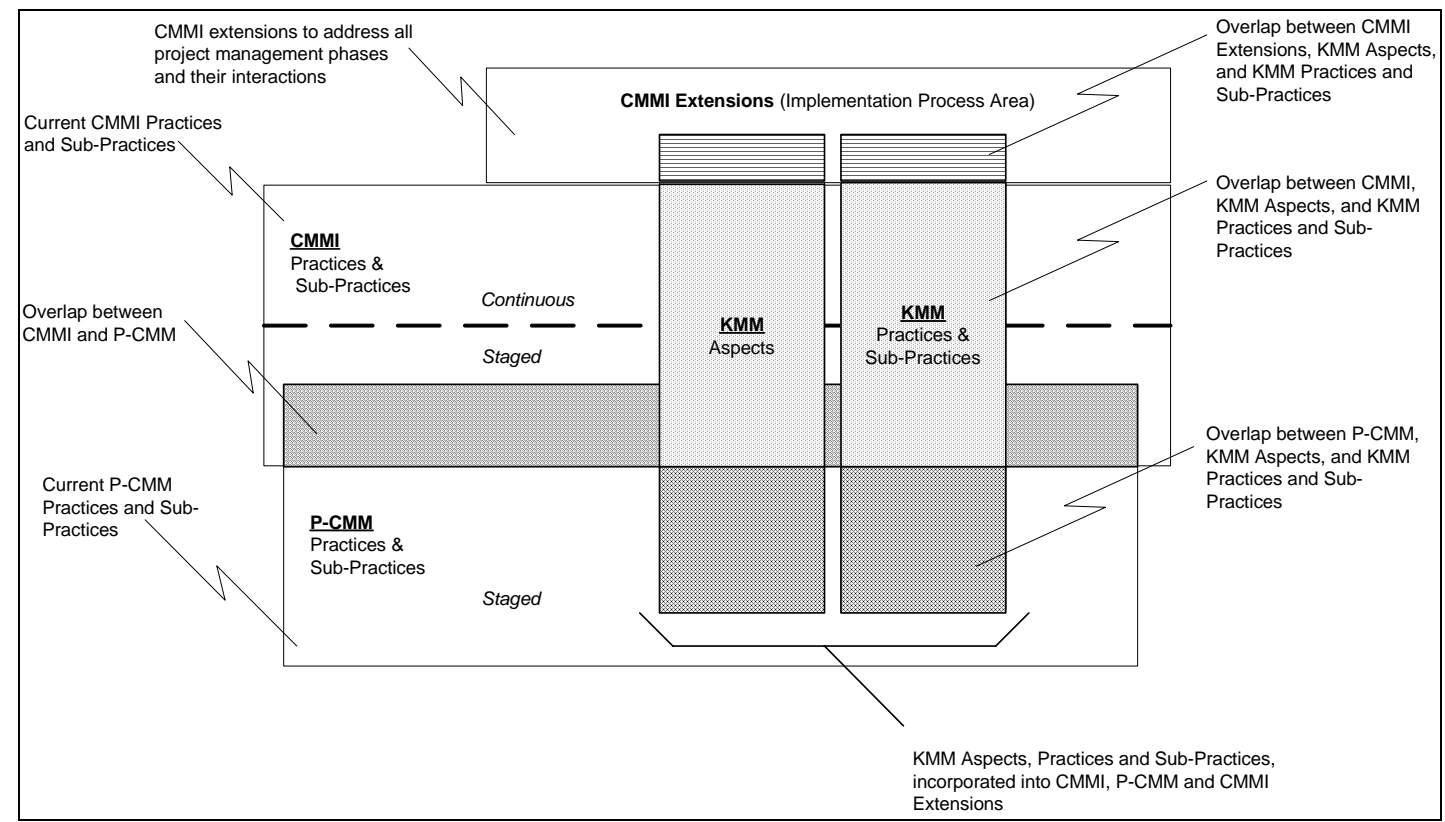

Figure 6: Conceptual blended model

\section{MODEL VALIDATION}

The blended model was partially validated at a management consultancy organisation, Waymark. The purpose of the validation was to demonstrate the appraisal process and simultaneous appraisal of $\mathrm{KM}$ practices and aspects while appraising selected CMMI Process Areas.

\subsection{Constraints regarding model validation}

Due to Waymark's requirement of appraising only selected process areas and specific projects, a staged representation (measuring the overall organisational maturity regarding the integrated domains) was not feasible. A continuous representation was more appropriate, limiting the scope to the following:

Appraising selected operational process areas, measuring against a capability level 3 (Defined), using CMMI. The selected process areas were:

- $\quad$ Project Planning.

- Requirements Development. 
- Requirements Management.

- Technical Solution.

- Product Integration.

- Verification.

Figure 7 portrays the scope of the validation exercise in terms of the complete blended model.

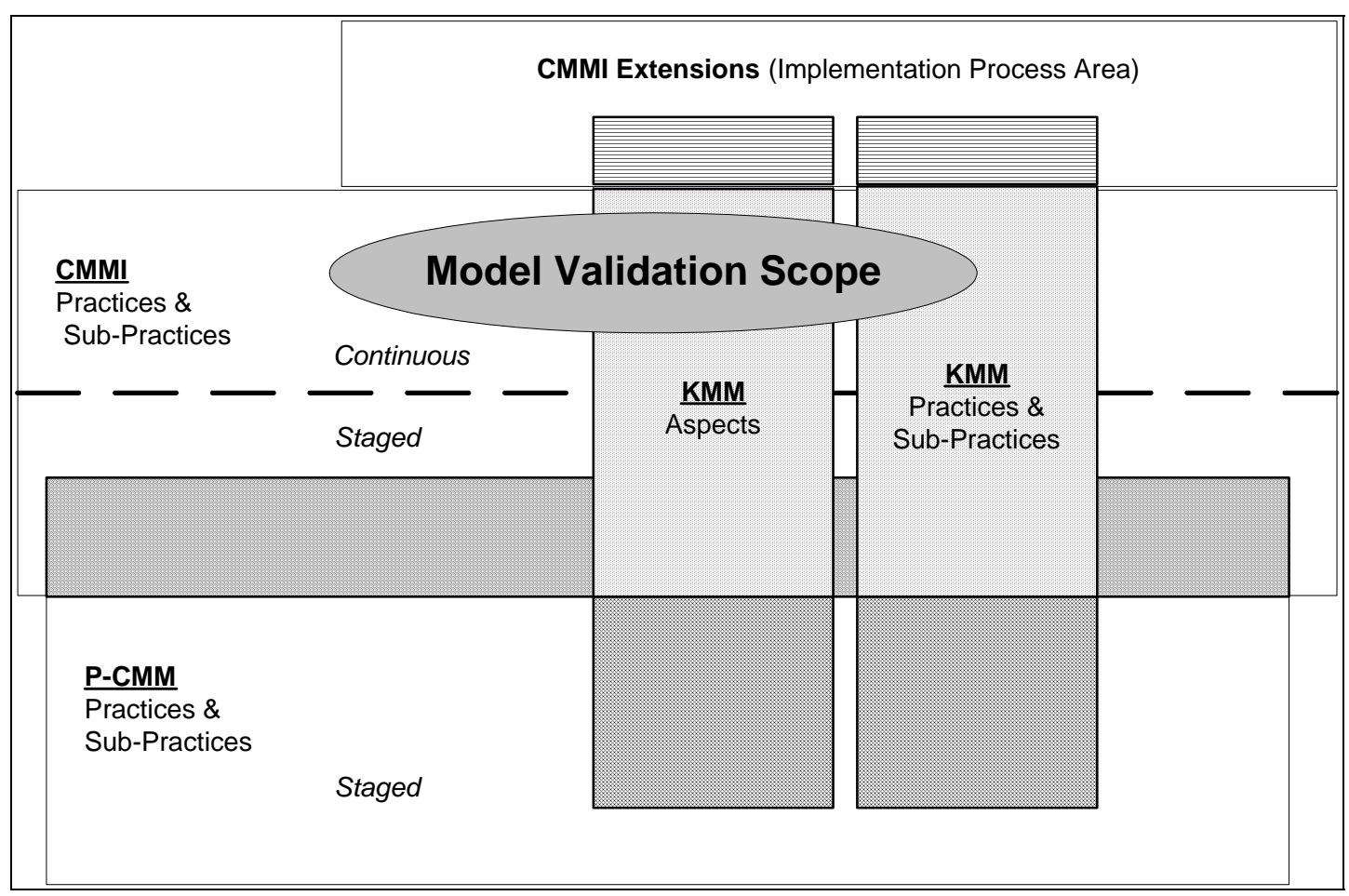

Figure 7: Model validation scope

\subsection{Appraisal results}

Two categories of appraisal results were delivered.

1. Appraisal of sub-practices of the selected set of process areas: the results revealed low scoring process areas that should receive high priority for improvement.

2. Appraisal of KM processes based on the sub-practices for the selected set of process areas: the results revealed low scoring process areas that should receive high priority for improvement regarding embedded KM processes. 


\section{CONCLUSIONS AND RECOMMENDATIONS}

\subsection{Conclusions}

The study supported the main endeavour of any industrial engineering endeavour, namely improving organisational performance. The study demonstrated the integration possibilities of the following domains: process improvement / knowledge / workforce-capability management. An informal content analysis confirmed the necessity of integrating process improvement and knowledge management efforts to leverage organisational performance.

Various maturity models (from process improvement, knowledge management, and workforce capability management domains) were investigated and evaluated for suitability in management consultancy organisations. Deficiencies were identified and a new, blended model was designed and constructed, which combined current maturity models and their required extensions.

The blended model was partially validated at a management consultancy organisation. Results were obtained, which highlighted organisational process areas that require immediate practice and KM improvement efforts.

\subsection{Recommendations}

Model validation was limited to a selected set of process areas that was measured against a capability level 3, using a continuous model representation. Validation of the complete blended model would also require appraisal against a specific maturity level, using a staged model representation.

It is recommended that further empirical research be performed in addressing the following:

1. Measuring and comparing the maturity levels of the synthesised domains (process-improvement / knowledge / workforce-capability management) for multiple consultancy organisations.

2. Measuring and comparing the capability levels of project management process areas for multiple consultancy organisations.

Though staged representation of maturity models provides a classification of processes and practices according to maturity levels that require increasingly sophisticated effort, this may also pose certain limitations. The validated organisation, for instance, indicated that it would gain more value from an appraisal exercise, if process areas were selected according to strategic objectives. Only certain process areas were thus selected, using the continuous representation of CMMI to perform the appraisal. A company may thus require a different growth path than that dictated by the staged representation of the blended model. Further research would be required to investigate the possibility of tailoring the blended model to an organisation's strategic objectives. 


\section{REFERENCES}

[1] Weerdmeester, R., Pocaterra, C. \& Hefke, M. D 5.2. Knowledge Management Maturity Model. Information Societies Technology (IST) Programme. [Online]. Available at http://km.aifb.unikarlsruhe.de/fzi/vision/vision/docs/D5.2-KM-Final.pdf. 2003.

[2] Eckes, G. The Six Sigma Revolution: How General Electric and Others Turned Process Into Profits, John Wiley \& Sons, New York, 2001.

[3] CMMI Product Team. Capability Maturity Model Integration (CMMI ${ }^{S M}$ ) Version 1.1, Staged Representation. Carnegie Mellon University, March 2002.

[4] Curtis, B., Hefley, W.E., Miller, S.A. People Capability Maturity Model (PCMM) Version 2. Carnegie Mellon University, July 2001.

[5] Kochikar, V.P. The knowledge management maturity model: a staged framework for leveraging knowledge. [Online]. Available at http://www.infy.com/knowledge_capital/KMWorld00_B304.pdf, 2000.

[6] Ahmed, P. K., Kok, L.K., \& Loh. A.Y.E. Learning through Knowledge Management, Butterworth-Heinemann, Oxford. 2002.

[7] Bahra, N. Competitive Knowledge Management, Palgrave, New York. 2001.

[8] Abell, A., \& Oxbrow, N. Competing with Knowledge, Library Association Publishing, London. 2001.

[9] Tiwana, A. The Knowledge Management Toolkit. Orchestrating IT, Strategy and Knowledge Platforms. Second Edition, Pearson Education Inc., USA. 2002.

[10] Dunford, R. Key challenges in the search for the effective management of knowledge in management consulting firms. Journal of Knowledge Management, Volume 4, Number 4, 2000, pp. 295-302.

[11] Werr, A. Exploring management consulting firms as knowledge systems, Organisation Studies, July 2003. [Online]. Available at http:www.findarticles.com/p/articles/mi_m4339/is_6_24/ai_105918454/print.

[12] Apostolou, D., \& Mentzas, G. Managing Corporate Knowledge: A comparative analysis of experiences in consulting firms. Second International Conference on Practical Aspects of Knowledge Management, 29-30 October, 1998, Basel, Switzerland, pp. 1 - 12.

[13] Harvard Business School. Managing Projects Large and Small. Harvard Business School Publishing Corporation, Boston. 2004.

[14] Disterer, G. Management of project knowledge and experience. Journal of Knowledge Management, Volume 6, Number 5, 2002, pp. 512-520.

[15] Carnegie Mellon University Software Engineering Institute (CMU/SEI). The Capability Maturity Model: Guidelines for Improving the Software Process, Addison Wesley, USA. 1994.

[16] Bourne, M., Franco, M., \& Wilkes, J. Corporate Performance Management. Measuring Business Excellence, Volume 7, No. 3, pp. 15 - 21.

[17] Maier, R., \& Remus, U. Towards a Framework for Knowledge Management Strategies: Process Orientation as Strategic Starting Point. Proceedings of the $34^{\text {th }}$ Hawaii International Conference on System Sciences, January 3 - 6, 2001, pp. $1459-1468$.

[18] Parlby, D. Knowledge Management Research Report 2000. [Online]. Available at: 
http://www.kpmg.nl/Docs/Knowledge_Advisory_Services/KPMG\%20KM\%20 Research\%20Report\%202000.pdf. 